\title{
Genetic Diversity and Population Structure of the Scallop Patinopecten yessoensis in Korea, China, and Japan by Random Amplified Polymorphic DNA Markers
}

\author{
Myung-Mo Nam', Chu Lee', Tae Seok Moon ${ }^{1}$ and Man Kyu Huh²* \\ ${ }^{1}$ Aquaculture Industry Division, East Sea Fisheries Research Institute, Gangneung-si, Gangwan-do 210-861, Korea \\ ${ }^{2}$ Department of Molecular Biology, Dongeui University 995 Eongwangno, Busanjin-gu, Busan 614714, Korea
}

Received January 31, 2012 /Revised March 9, 2012 /Accepted March 15, 2012

\begin{abstract}
Sixty individuals of the scallop Patinopecten yessoensis (Genus Pecten) were sampled to examine the genetic diversity and population structure of this species. Random amplified polymorphic DNA (RAPD) identified 109 genotypes and produced 79 polymorphic loci $(72.8 \%)$. Total genetic diversity values $\left(H_{\Gamma}\right)$ and interlocus variation in the within-population genetic diversity $\left(H_{\mathcal{S}}\right)$ were 0.254 and 0.178 , respectively. On a per-locus basis, the proportion of total genetic variation due to differences among populations $\left(G_{\mathrm{ST}}\right)$ was 0.299 . This indicated that about $70.1 \%$ of the total variation was within populations. The unique loci and bands of $P$. yessoensis were shown in only one population among the three countries. RAPD markers were very effective in classifying the natural population levels of $P$. yessoensis in Korea, China, and Japan. In addition, insights into the relative gene diversity among and within populations of $P$. yessoensis would be useful in breeding and for the development of strategies for animal genetic resources.
\end{abstract}

Key words : Random amplified polymorphic DNA (RAPD), genetic diversity, Patinopecten yessoensis

\section{Introduction}

Bivalves comprise 30,000 extant species, constituting the second largest group of mollusks. However, limited genetic research has focused on this group of animals so far, which is, in part, due to the lack of genomic resources. Patinopecten (Mizuhopecten) yessoensis (Yesso scallop, Giant Ezo scallop, Ezo giant scallop) is a species of scallop and one of marine bivalve mollusks in the family Pectinidae. Its name Yesso/Ezo refers to its being found north of Japan. The Japanese scallop, $P$. yessoensis is a cold-tolerant species inhabiting coastal waters of the northern islands of Japan, the northern part of the Korean Peninsula, and Russian Primorye, Sakhalin and possibly as far north as the Kamchatka Peninsula and the Aleutian Islands [7].

This species is aqua-farmed in China, South Korea, Japan, and Russia, with over 1,400,000 tones worth over US\$373 million harvested in 2007 [4]. This commercially valuable Pacific Asian low-boreal scallop species supported substantial fisheries until the 1930s; then stocks diminished mainly through over-exploitation. Capture fisheries production appears to have peaked in the mid-1930s when 80,000 tones (shell-on) were landed in Japan

*Corresponding author

Tel : +82-51-890-1521, Fax : +82-51-890-1529

E-mail : mkhuh@deu.ac.kr (http://www.thefishsite.com/articles). At about the same time, the Russian Yesso scallop population along the coast of Primorye was estimated at about 40 million, inhabiting an area of about 16,000 ha (http://www.thefishsite.com/articles). Regional catches declined dramatically thereafter, falling to 6,000 tones in Japan in 1968. The development of off-bottom culture, supported by wild seed capture after 1945 led to a sustained upsurge in production, which continued until the year 2000. Since then annual production has stabilized at 1.1-1.2 million tones. China and Japan are the major producers, together accounting for over 1.1 million tons in 2003 (http://www.fao.org/fishery/culturedspecies).

The scallop is an economically important species, particularly in Japan, where it is mainly cultured in Hokkaido prefecture, and the production reached 287,000 metric tons in 2005 [8].

Many megabenthic species living in soft sediment exhibit contagious distributional patterns, grouping together in large patches or beds. However, their spatial distribution tends to be more dispersed or random within patches [1].

Analysis of geographic distribution requires precise estimates of localities and genetic diversity that are also necessary in the management of this edible resource. Although there are several studies on distribution and population estimates of a number of scallop species [2,9,12], little work has been done on P. yessoensis. 
In this study, three populations of $P$. yessoensis from Korea, China and japan were analyzed for RAPD (random amplified polymorphic DNA) markers. RAPD assay has been useful in determining genetic relationships among closely related species [13]. RAPD analysis is quick, robust, requires minimal preliminary work [11].

However, the genetic diversity and population structure of $P$. yessoensis in East Asia has not been studied. The basic question is to detect the identification of cultivated populations using RAPD makers.

This study was carried out to examine three populations of $P$. yessoensis in order to evaluate genetic diversity and population structure in this species.

\section{Materials and Methods}

\section{DNA extraction and RAPD procedure}

The matured scallops are captured by collectors suspended in mid water in June when fully developed larvae are abundant. Sixty individuals of $P$. yessoensis were sampled from three natural populations (Table 1). The distance between the selected individuals was about $20 \mathrm{~m}$ to avoid including individuals emanating from the same lineage. Samples were labeled by removing a portion of the fresh foot. DNA was extracted from tissues of samples with the DNA Zol Kit (Life Technologies Inc., Grand Island, New York, USA) according to the manufacturer's protocol.

RAPD analysis was performed using 60 different 10-base oligonucleotide primers (OPA-01 20, OPB-01 20, and OPC-01 20, series) purchased from Operon Technologies (Alameda, CA). A mixture contained $20 \mathrm{ng}$ of template DNA, 0.5 pmol of a random primer, 10x PCR buffer $(20 \mathrm{mM}$ Tris- $\mathrm{HCl} \mathrm{pH}$ 8.4, $50 \mathrm{mM} \mathrm{KCl}$ ), $3.0 \mathrm{mM} \mathrm{MgCl}, 2.5 \mu \mathrm{M}$ each $\mathrm{dNTP}$, and 1.0 U Taq DNA polymerase. Amplification was performed in a Gene Amp PCR System 9700 (Perkin Elmer Applied Biosystems, Foster City, CA), which was programmed for initially denatured at $94^{\circ} \mathrm{C}$ for $30 \mathrm{sec}$, followed by 40 cycles of $40 \mathrm{sec}$ of denaturation at $94^{\circ} \mathrm{C}, 40 \mathrm{sec}$ of annealing at $40^{\circ} \mathrm{C}$ and $60 \mathrm{sec}$ of primer extension at $72^{\circ} \mathrm{C}$, then finally incubated at $72^{\circ} \mathrm{C}$ for $7 \mathrm{~min}$. A $100 \mathrm{bp}$ ladder DNA marker was used in the end of gels for the estimation of fragment size. Because RAPD markers had a disadvantage of reproduction, all experiments were done twice.

The amplification products were separated by electrophoresis on $1.5 \%$ agarose gels, stained with ethidium bromide, and photographed under UV light using Alpha Image TM (Alpha Innotech Co., USA).

\section{Statistical analyses}

All RAPD bands were scored by eye and only unambiguously scored bands were used in the analyses. Because RAPDs are dominant markers, they were assumed that each band corresponded to a single character with two alleles, presence (1) and absence (0) of the band, respectively. Loci were named based on the primer and observed band size.

The following genetic parameters were calculated using a POPGENE computer program (ver. 1.31) developed by Yeh et al. [19]: allele frequencies, the percentage of polymorphic loci $\left(P_{\mathrm{p}}\right)$, mean numbers of alleles per locus $(A)$, effective number of alleles per locus $\left(A_{\mathrm{E}}\right)$, gene diversity $(H)$, and Shannon"s index of phenotypic diversity [6].

The estimation of genetic similarity (GS) between genotypes was based on the probability that an amplified fragment from one individual will also be present in another. GS was converted to genetic distance (1-GS). Homogeneity of variance among accessions was tested by Bartlett's statistics.

The Mantel test was examined the correlation between the matrix of genetic distance and spatial distance within a site.

A genetic relationship was constructed by the neighbor joining (NJ) method [14] using the NEIGHBOR program in MEGA5 [16].

\section{Results}

From the sixty decamer primers used for a preliminary RAPD analysis, eleven primers of them produced good amplification products both in quality and variability (Table 2).

Table 1. Accessions used in the molecular study of the Patinopecten yessoensis including population locations

\begin{tabular}{lll}
\hline Population & Collecting site & Coordinate \\
\hline Yeongok & Haean-ro, Yeongok-myeon, Gangneung-si, Ganwon-do, Korea & $37^{\circ} 52^{\prime}$ N, $128^{\circ} 51^{\prime}$ E \\
Taipinwan & Taipinwan, Qingdao, Shandong, China & $36^{\circ} 01^{\prime}$ N $120^{\circ} 22^{\prime} \mathrm{E}$ \\
Tokoro & Tokoro, Hokkaido, Japan & $44^{\circ} 13^{\prime} \mathrm{N}^{\prime} 143^{\circ} 55^{\prime} \mathrm{E}$ \\
\hline
\end{tabular}


Table 2. Lists of decamer oligonucleotides utilized as primers, their sequences, and associated fragments amplified in $P$. yessoensis

\begin{tabular}{|c|c|c|c|c|c|}
\hline \multirow{2}{*}{ Primer } & \multirow{2}{*}{$\begin{array}{c}\text { Sequence } \\
\left(5^{\prime}->3^{\prime}\right)\end{array}$} & \multirow{2}{*}{$\begin{array}{c}\text { No. of } \\
\text { fragments }\end{array}$} & \multirow{2}{*}{$\begin{array}{c}\text { No. of } \\
\text { polymorphic bands }\end{array}$} & \multicolumn{2}{|c|}{ Specific bands } \\
\hline & & & & Locus & Population \\
\hline OPA-01 & CAGGCCCTTC & 3 & 2 & & \\
\hline OPA-04 & AATCGGGCTG & 7 & 4 & & \\
\hline OPA-12 & TCGGCGATAG & 14 & 9 & $\begin{array}{c}01 \\
03.05 .07 .12 .14\end{array}$ & $\begin{array}{c}\text { Taipinwan } \\
\text { Tokoro }\end{array}$ \\
\hline OPB-05 & TGCGCCCTTC & 12 & 7 & 01 & Taipinwan \\
\hline OPB-06 & TGCTCTGCCC & 5 & 5 & & \\
\hline OPB-07 & GGTGACGCAG & 6 & 3 & & \\
\hline OPB-17 & AGGGAACGAG & 13 & 9 & 01 & Tokoro \\
\hline OPB-18 & CCACAGCAGT & 14 & 12 & 01 & Yeongok \\
\hline & & & & 14 & Tokoro \\
\hline OPB-19 & ACCCCCGAAG & 12 & 9 & & \\
\hline OPB-20 & GGACCCTTAC & 9 & 8 & & \\
\hline OPC-05 & GATGACCGCC & 14 & 10 & $01,02,10$ & Tokoro \\
\hline
\end{tabular}

Table 3. Measures of genetic variation for $P$. yessoensis. The number of polymorphic loci $(\Lambda \bar{p})$, percentage of polymorphism $(I \mathrm{p})$, mean number of alleles per locus $(A)$, effective number of alleles per locus $\left(A_{\mathrm{E}}\right)$, gene diversity $(H)$, and Shannon's information index $(\Lambda$

\begin{tabular}{lcccccc}
\hline Population & $N p$ & $P \mathrm{p}$ & $A$ & $A_{\mathrm{E}}$ & $H$ & $I$ \\
\hline Yeongok & 45 & 41.3 & 1.413 & 1.314 & 0.174 & 0.252 \\
Taipinwan & 54 & 49.5 & 1.495 & 1.290 & 0.169 & 0.254 \\
Tokoro & 55 & 50.5 & 1.505 & 1.342 & 0.192 & 0.282 \\
Mean & 51.3 & 47.1 & 1.471 & 1.315 & 0.178 & 0.263 \\
Species & 79 & 72.5 & 1.725 & 1.440 & 0.254 & 0.379 \\
\hline
\end{tabular}

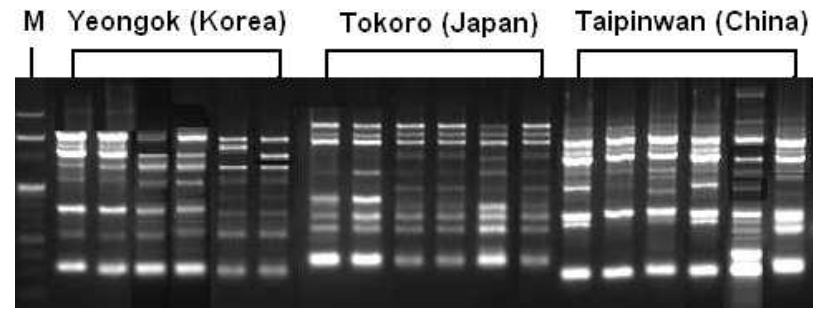

Fig. 1. DNA bands obtained from $P$. yessoensis amplified with OPA-12 primer. M: Molecular weight of standard.

For the sixty samples, these eleven primers produced 109 scorable bands, 79 of which were polymorphic (85.5\%). Fig. 1 showed the amplified products of the primer OPA-11.

The unique loci and bands of $P$. yessoensis were shown in only one population among three countries (Fig. 2). The unique multilocus genotypes which were not share with other populations were two in Korean population. The unique multilocus band which was not share with other populations and other animals within same population was one in the Korean population (Table 2). Chinese unique loci and bands were three and two, respective. Japanese unique loci and bands were ten and four, respective. These results were very informative to identify of populations of $P$. yessoensis.

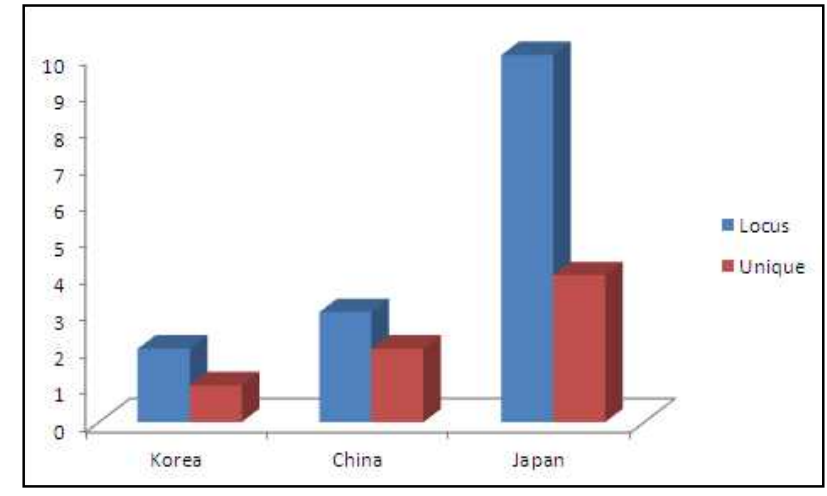

Fig. 2. Unique loci and bands of $P$. yessoensis were shown in only one country among three countries. Locus: the unique locus is shown only one population which is not share with other populations. Unique: the unique band is shown only one animal which is lacked other animals within same population as well as other populations.

Across populations, the average number of alleles per locus $(A)$ was 1.513 , ranging from 1.413 to 1.505 (Table 3 ). The effective numbers of alleles per locus $\left(A_{\mathrm{E}}\right)$ at the species $\left(A_{\mathrm{ES}}\right)$ and the population levels $\left(A_{\mathrm{EP}}\right)$ were 1.440 and 1.315, respectively. Mean genetic diversity within populations was 0.178. In particular, the Japanese population had the highest 
Table 4. Estimates of genetic diversity of $P$. yessoensis. Total genetic diversity $\left(H_{\mathrm{I}}\right)$, genetic diversity within populations $\left(H_{s}\right)$, the proportion of total genetic diversity partitioned among populations $\left(G_{\mathrm{ST}}\right)$, and gene flow $(N m)$

\begin{tabular}{|c|c|c|c|c|c|}
\hline Locus & Sample Size & $H_{\Gamma}$ & $H_{S}$ & $G_{\mathrm{ST}}$ & $N m$ \\
\hline OPA-01 & 60 & 0.478 & 0.309 & 0.323 & 0.919 \\
\hline OPA-04 & 60 & 0.339 & 0.304 & 0.104 & 16.643 \\
\hline OPA-12 & 60 & 0.155 & 0.105 & 0.201 & 4.475 \\
\hline OPB-05 & 60 & 0.394 & 0.291 & 0.258 & 7.423 \\
\hline OPB-06 & 60 & 0.439 & 0.214 & 0.479 & 6.705 \\
\hline OPB-07 & 60 & 0.302 & 0.207 & 0.297 & 1.992 \\
\hline OPB-17 & 60 & 0.429 & 0.351 & 0.184 & 5.563 \\
\hline OPB-18 & 60 & 0.353 & 0.213 & 0.364 & 1.468 \\
\hline OPB-19 & 60 & 0.401 & 0.302 & 0.226 & 2.758 \\
\hline OPB-20 & 60 & 0.369 & 0.206 & 0.407 & 0.933 \\
\hline OPC-05 & 60 & 0.266 & 0.215 & 0.140 & 5.609 \\
\hline Mean & 60 & 0.254 & 0.178 & 0.299 & 1.174 \\
\hline
\end{tabular}

Table 5. Genetic identity (upper diagonal) among populations of $P$. yessoensis and genetic distances (low diagonal) based on RAPD analysis

\begin{tabular}{lccc}
\hline Country & Yeongok & Taipinwan & Tokoro \\
\hline Yeongok & - & 0.868 & 0.851 \\
Taipinwan & 0.141 & - & 0.865 \\
Tokoro & 0.162 & 0.145 & - \\
\hline
\end{tabular}

expected diversity $(H=0.192)$; the Chinese population, the lowest (0.169). Mean Shannon's information index (I) was 0.263 , ranging from 0.251 to 0.282 .

Total genetic diversity values $\left(H_{\mathrm{T}}\right)$ and interlocus variation in the within-population genetic diversity $\left(H_{\mathcal{S}}\right)$ were 0.254 and 0.178 , respectively (Table 4 ). On a per-locus basis, the proportion of total genetic variation due to differences among populations $\left(G_{\mathrm{ST}}\right)$ was 0.299 . This indicated that about $29.9 \%$ of the total variation was among populations. These values indicate that most of the genetic diversity of $P$. yessoensis is found within populations and there is a little among-population differentiation. The estimate of gene flow, based on $G_{S T}$, was slightly low among populations of $P$. yessoensis $\left(N_{m}=1.174\right)$.

Values of genetic distance (D) were $<0.162$ (Table 5). Genetic identity values among pairs of populations ranged from 0.851 to 0.868 .

The Mantel test was used to test for correlations between the matrix of genetic diversity and spatial distance. Genetic diversity correlated with spatial distance in $P$. yessoensis populations.

Clustering of accessions was performed based on the matr ix of calculated distances using the NJ algorithm (Fig. 3).

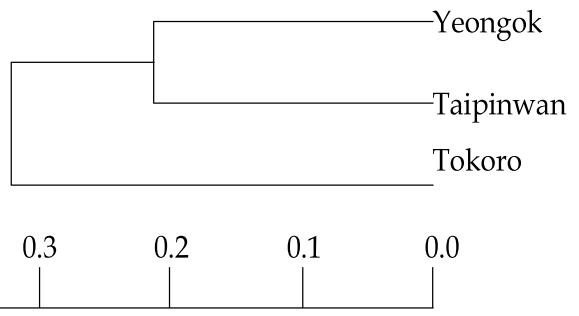

Fig. 3. A phenogram showing the relationships among three populaions based on data of genetic distance obtained by RAPD.

In dendrogram, all populations were well separated from each other. Thus, RAPD markers are very effective in classifying natural population levels of $P$. yessoensis in East Asia. Korean population was similar to Chinese population and sistered to Japanese population.

\section{Discussion}

Three $P$. yessoensis populations with 60 individuals included 109 genotypes, 13 of which were restricted to a single population. Three multilocus genotypes were shared by more than one animal within a population (Fig. 2). Because 
clustering of $P$. yessoensis is considered mainly sexual reproduction, it is expected that the shared genotypes among individuals at a long distance is the result of sib lines by random mating. Unlike many species of scallop, sexes are separate with hermaphrodites rarely observed [10]. Yesso scallops are protandrous hermaphrodites maturing initially as males and changing sex to female as they age [10]. Spawning occurs in spring as water temperature rises and reaches $7-12^{\circ} \mathrm{C}$ [15]. Males dominate in younger year classes and females in older year classes. Females of 12-15 cm shell height produce 8-18 million eggs.

In RAPD analysis, $P$. yessoensis maintains a higher than average level of genetic diversity (Table 3 ). The same trends are observed at other genetic parameters such $A$ and $A$ E. Thus, the high genetic diversity resulted from outcrossing. The results were consistent with other scallops. The mean $H$ with microsatellite markers and the haplotype diversity with mitochondrial markers were at high levels in all populations examined [8]. Hence the likelihood of a parent producing an identical offspring should increase the probability of identical genotypes from independent sexual events.

At natural populations, $P$. yessoensis could not be responsible for long distance dispersal events. It is expected the sperms are disperse only a short distance from the parents, producing a patchy distribution. The Mantel test supported this by showing correlation between genetic distance and spatial distribution. The data are consistent with the dispersal of spat being an important factor in the population structure of this species. It is possible that some of these disjunctive identical genotypes were formed by neighboring individuals.

In 1982, P. yessoensis were first introduced into China from Japan by the Marine Fishery Research Institute of Liaoning province to increase scallop cultivation in the northern parts of the Chinese coast [18]. As it is larger in size and commands a higher market price than the native zhikong scallop Chlamys farreri and introduced bay scallop Argopecten irradians, $P$. yessoensis quickly gained acceptance by scallop farmers in northern China, and aquaculture expanded rapidly after 1982. It is in good agreement with the concept that most derivation populations show a reduced level of polymorphisms as compared to their presumed progenitors $[3,17]$. However, the Chinese population of $P$. yessoensis maintains a similar to average level of genetic diversity compared with the Japanese population. Why is maintained the relatively high level of genetic variation in Chinese pop- ulation of $P$. yessoensis? Thus, it is assumed that the introduced animals may be maintained considerably high levels of germplasms or large samples enough to prevent genetic erosion due to genetic drift, natural selection, and consanguineous-breeding. Thus, this knowledge of genetic diversity is essential for the formulation of sampling strategies that capture variation within species.

\section{Acknowledgement}

Research supported by the National Fisheries Research and Development Institute (NFRDI) in Korea (\#RP-2012-AQ-34).

\section{References}

1. Brand, A. R. 1991. Scallop ecology: distribution and behavior, pp. 517-584, In Shumway, S. E. (ed.), Scallops: Biology, Ecology and Aquaculture, Elsevier, Amsterdam.

2. Caddy, J. F. 1970. A method of surveying scallop populations from a submersible. J. Fish Res. Bd Can. 27, 535-549.

3. Doebley, J. 1989. Isozymic evidence and the evolution of crop plants, pp. 46-72, In Soltis, D. E. and P.S. Soltis (eds.), Isozymes in Plant Biology, Dioscorides Press, Portland.

4. Fisheries Global Information System. 2010. Food and Agriculture Organization of the United Nations.

5. Goshima, S. and Fujiwara, H. 1994. Distribution and abundance of cultured scallop Patinopecten yessoensis in extensive sea beds as assessed by underwater camera. Mar. Ecol. Prog. Ser. 110, 151-158.

6. Hedrick, P. W. 1998. Maintenance of genetic polymorphism: spatial selection and self-fertilization. Am Nat. 152, 145-150.

7. Ito, H. 1991. Patinopecten (Mizuhopecten) yessoensis, pp. 1024-1055, In Shumway, S. E. (ed.), Scallops: Biology, Ecology and Aquaculture, Elsevier, Amsterdam.

8. Li, Q., K. Xu, and R. I. Yu. 2007. Genetic variation in Chinese hatchery populations of the Japanese scallop (Patinopecten yessoensis) inferred from microsatellite data. Aquaculture 269, $211-219$

9. MacDonald, B. A. and Bajdik, C. D. 1992. Orientation and distribution of individual Placopecten magellanicus (Gmelin) in two natural populations with differing production. Can. J. Fish Aquat. Sci. 49, 2086-2092.

10. Martinez, G., Mettifogo, L., Perez, M. A. and Callejas, C. 2007. A method to eliminate self-fertilization in a simultaneous hermaphrodite scallop. 1. Effects on growth and survival of larvae and juveniles. Aquaculture 273, 459-469.

11. Molnar, S. J., James, L. E. and Kash, .K. J. 2000. Inheritance and RAPD tagging of multiple genes for resistance to net blotch in barley. Genome 43, 224-231.

12. Olsen, A. M. 1955. Underwater studies on the Tasmanian commercial scallop, Notovola mendionalis (Tate) (Lamel libranchiata. Pectinidae). Aust. J. mar. Freshwat. Res. 6, 392-409.

13. Pacak, A., Fiedorow, P., Dabert, J. and Szweykowska-ku- 
lińska, Z. 2010. RAPD technique for taxonomic studies of Pellia epiphylla-complex (Hepaticae, Metzgeriales). Genetica. 104, 179-187.

14. Saitou, N. and Nei, M. 1987. The neighbor-joining method: A new method for reconstructing phylogenetic trees. $\mathrm{Mol}$. Biol. Evol. 4, 406-425.

15. Sato, M., Kawamata, K., Zaslavskaya, N., Nakamura, A., Ohta, T., Nishikiori, T., Brykov, V. and Nagashima, K. 2005. Development of microsatellite markers for Japanese scallop (Mizuhopecten yessoensis) and their application to a population genetic study. Marine Biotech 7, 713-728.

16. Tamura, K., Peterson, D., Peterson, N., Stecher, G., Nei, M., and Kumar, S. 2011. MEGA5: Molecular evolutionary genetics analysis using maximum likelihood, evolutionary distance, and maximum parsimony methods. Mol. Biol. Evol. 28, 2731-2739.

17. Van Treuren, R., Bijlsma, R., van Delden, W. and Ouborg, N. J. 1991. The significance of genetic erosion in the process of extinction. I. Genetic differentiation in Salvia pratensis and Scabiosa columbaria in relation to population size. Heredity 66, 181-189.

18. Wang, Q. C. 1984. Introduction of Japanese scallop and prospect of culture it in northern China. Fish Sci. 3, 24- 27.

19. Yeh, F. C., Yang, R. C., Botle, T. J., Ye, Z. H. and Mao, J. X. 1997. POPGENE, the user friendly shareware for population genetic analysis. Molecular Biology and Biotechnology Centre, University of Alberta, Edmonton, Canada.

\section{초록 : RAPD 마커에 의한 한국, 중국, 일본 참가리비의 유전적 다양성과 집단 구조

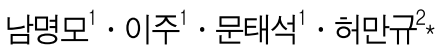 \\ ('국립수산과학원, ${ }^{2}$ 동의대학교 분자생물학과)}

참가리비(Patinopecten yessoensis) 60개체를 채집하여 유전적 다양성과 집단구조를 조사하였다. 임의 유전 다형 성 DNA (RAPD)로 109 개 유전자형과 79 개 다형성 좌위 $(72.8 \%)$ 를 발견하였다. 전체 유전적 다양도 $\left(H_{\mathrm{I}}\right)$ 와 집단 내 변이 $\left(H_{5}\right)$ 는 각각 0.254 와 0.178 였다. 유전자 좌위에 근거하여 집단 간 분화 정도 $\left(G_{S T}\right)$ 는 0.299 였다. 이는 전체 변이의 약 $70.1 \%$ 가 집단 내에 존재하고 있음을 시사한다. 참가리비 세 나라 집단에서 한 집단에 국한되는 대립유 전자 좌위와 한 개체에만 발현된 밴드가 발견되었다. RAPD 마커는 한국, 중국, 일본에 분포하는 참가리비를 구 분하는데 매우 효과적이었다. 또한 참가리비의 집단 내, 집단 간 유전적 다양성에 대한 통찰은 동물 유전자원의 수진 전략과 양식에 유익할 것으로 사료된다. 